\title{
Teachers' Perspectives on Remote-based Teaching and Learning in the COVID-19 Era: Rethinking Technology Availability and Suitability in Zimbabwe
}

\author{
Vusumuzi Maphosa ${ }^{1 *}$ (D)
}

${ }^{1}$ Lupane State University, Lupane, ZIMBABWE

*Corresponding Author: vmaphosa@lsu.ac.zw

Citation: Maphosa, V. (2021). Teachers' Perspectives on Remote-based Teaching and Learning in the COVID-19 Era: Rethinking Technology Availability and Suitability in Zimbabwe. European Journal of Interactive Multimedia and Education, 2(1), e02105. https://doi.org/10.30935/ejimed/9684

\begin{abstract}
The outbreak of the coronavirus pandemic (SARS-COV-2) in December 2019 disrupted traditional forms of teaching and learning centred on face-to-face and in-class instruction. Governments enforced social distancing measures characterised by stay-at-home strategies and the closure of schools and other learning facilities. The government of Zimbabwe adopted radio broadcast as the primary tool for lesson delivery during the COVID-19. Contextually, Zimbabwe's radio signals are only accessed by 29.1 percent of the entire population, with weak to no reception in some regions, especially those in the south. While radio access is low, mobile phone ownership per household is over 90 percent. In light of the contextual dynamics, the study examined available technologies to deliver educational content during the COVID-19 lockdown as the government declared radio broadcasts as the primary tool to support teaching and learning. The study utilised an adapted Technology Acceptance Model as the theoretical framework. Secondary school teachers from the southern region were drawn through random sampling to participate in the survey to gather their opinions and practices. The study results revealed that teachers preferred to use smartphones and computers/laptops for teaching rather than radio. The study identified barriers such as lack of infrastructure, cost of data, lack of connectivity, lack of access to computing devices, and the institution's culture. The results could influence policymakers in adopting digital media for teaching, and this will equip learners with 21st-century skills. Continuous professional development of teachers should aim to improve their digital skills.

Keywords: COVID-19, radio, instructivism and constructivism, 21st-century learning, Technology Acceptance Model

Received: 22 Sep. 2020 Accepted: 24 Nov. 2020
\end{abstract}

\section{INTRODUCTION}

The rapid developments in information and communication technologies (ICT) have influenced every aspect of human life, including education. Digital tools have influenced the growth and development of young people. ICTs have transformed the traditional teacher-centred classroom to a learner-centred paradigm, offering an interactive and collaborative resource-rich environment that fosters participation and information sharing (Hunde \& Tegegne, 2010; Montrieux et al., 2015; Zhu \& Li, 2020). Papadakis and Kalogiannakis (2017) reported that mobile phones provide a new and innovative way that has rejuvenated the teaching and learning processes around the world. The new ways offer learners active participation, flexibility, and freeing them from location and time constraints. Papadakis (2018) contended that mobile devices provided features such as real-time access to information, communication, context awareness, and feedback that could support self-directed learning. In developed countries, learners access rich digital tools at home where they learn to create content, solve problems, engage, collaborate, and network, thereby laying a foundation for 21st-century skills acquisition (Papadakis \& Kalogiannakis, 2017; Rambe \& Bere, 2013). The integration of ICTs in education has increased student satisfaction and engagement. Wahab (2020) notes that the education system must rapidly embrace emerging technologies to support remote learning. Globally, the number of online enrollments has been steadily increasing, highlighting online learning's potential as an alternative to face-to-face education (Mouchantaf, 2020). The outbreak of pandemics and natural disasters have shown that teaching and learning are not confined to the four walls but have shown how education and technology are intertwined (Wargo, Chellman, Budge, \& Davis, 2020). The global education system must adapt to the new norm, moving away from the conventional face-to-face to virtual and online learning amid the COVID-19 pandemic. Educational institutions that had integrated ICTs in their curriculum found it easy to switch to remote-based teaching and learning. 
The global outbreak of the acute respiratory syndrome coronavirus 2 (SARS-COV-2), the virus that causes COVID-19 had devastating effects on human life (Baldwin \& di Mauro, 2020). The virus spreads through close contact with infected people and contaminated surfaces. In response, many governments banned face to face teaching, leading to the widespread adoption of remote-based education. Over half a billion of school-going children and youth missed classes as governments implemented lockdowns (Wahab, 2020). The forced schools' closure, affected about 4.56 million learners in Zimbabwe who depended on face-to-face and in-class instruction (OCHA, 2020). To ensure uninterrupted teaching and learning, schools and other learning institutions sought alternative education delivery from radio broadcasts to online-based. The Zimbabwe government declared radio broadcasts as the primary tool to support teaching and learning during the pandemic. The country's contextual dynamics led to the examination and evaluation of the suitability of available technologies to deliver educational content during the COVID-19 lockdown. Sharma (2020) reported that school opening was going will delay further as there were fears that the physical distancing and safety bounds may be broken, thus escalating the transmission of the pandemic. As no cure for COVID-19 is available, remote-based learning will supplement traditional face-toface teaching, which is under threat for the foreseeable future. Before the COVID-19 outbreak, Zimbabwe's government through the Ministry of Primary and Secondary Education (MoPSE) had introduced a competency-based curriculum that focused on specialisations with learners taking up to 10 or more subjects (MoPSE, 2020). The curriculum review was motivated by the realisation that learners had to acquire 21-st century and future skills that would enable them to live and compete in the knowledge economy. Lack of such skills may hinder young people from participating in the national and global socioeconomic development.

The International Telecommunications Union (ITU) reported that for the first time, the number of mobile-broadband subscriptions in the developing world exceeded those of the developed world (ITU, 2018). A study conducted across sub-Saharan Africa found that the mobile phone had improved learners' academic performance aided by its communicational capabilities (Porter et al., 2015). In Zimbabwe, the proportion of households with at least one household member owning a mobile cellular telephone at home was about 106 percent in 2014 (Zimstats, 2018). Zimbabwe's number of active internet subscriptions increased to over 8 million subscribers during the same period. Smartphone ownership in the country has been growing, and it had reached 60.6 percent by August 2018 (Karombo, 2018; POTRAZ, 2019). About 29.1 percent of the Zimbabwean population has access to the radio (Zimstats, 2018). However, Zimbabwe partnered with UNICEF to broadcast radio lessons during the COVID-19 lockdown (MoPSE, 2020).

Developing countries can take advantage of ICTs, improve access to education for impoverished communities through enhanced access to and acquisition of information (Mikre, 2011). A study conducted across South Africa, Ghana, and Malawi revealed that mobile phones had improved learning opportunities and enabled learners to discover their potential and identity (Porter et al., 2015). Technology-based learning can bridge barriers associated with a traditional curriculum as it allows learning to occur in every learner's environment (Talebiana et al., 2014), which is critical when face-to-face learning is no longer possible. Digital media has the same disruptive power that saw the shift from oral language to print literacy (Radich, 2013). Similarly, Click and
Karkos (2011) concluded that this change was so rapid and disruptive, and similar to how print disposed of oral literacy, which led to broader access to books. Today's learners get exposed to digital technologies that are evolving at a swift pace; their grandparents witnessed radio, television, and newspapers as technologies of the day (Radich, 2013). Learners must be allowed to use their day's technology as forcing them to use another generation's technology may not be effective in their teaching and learning.

\section{LITERATURE REVIEW}

The advent of the knowledge economy has transformed the learning process by equipping learners with the technological tools that allow them to create new knowledge, interact, collaborate, and learn at their own pace. For any meaningful learning to occur during the COVID-19 pandemic, learners must access tools that support flexible learning at their location, own speed, and time. ICTs have proved to be a useful tool in promoting student-centred learning by offering varied, well designed, and visually appealing educational content (Alenezi, 2019). Today's learners prefer to learn informally without the hindrance of space and time. Learning embedded with ICTs motivates learners and enables them to engage in activities that support coviewing and co-participation (Wahab, 2020). Zaranis et al. (2013) revealed that ICTs allowed learners to quickly acquire knowledge about their environment and developed functional skills as they operated digital media that foster teamwork. This form of learning is more effective than traditional education delivery.

The developed world has invested in big data, Internet of Things, Artificial Intelligence, 5G and cloud-based technologies to sustain teaching and learning during the COVID-19 lockdown (Zhu \& Li, 2020). Bedesem and Arner (2019) noted widespread ownership of smartphones and tablets among school-aged youth in developed countries. A European Union comprehensive survey revealed that 70 percent of educators in its bloc had acknowledged the critical role that education played through systematic integration of technology by over 90 percent of the teachers (Buda, 2020). Results of a survey covering 190,000 learners in Europe revealed the general use of ICTs in schools, though usage at home was higher (Pullen, 2015). A study in the United States of America revealed that over 70 percent of teenagers own a smartphone, which they use for learning, games, social media, and shopping (Kabali et al., 2015). Pullen (2015) noted that 91 percent of households with children in Australia had a computer at home, with 86 percent of them having internet at home. A study conducted in Greece revealed that 55 percent of the parents were willing to offer their smartphones for learning as they felt that lack of access to digital media would result in their children lagging in schoolwork (Papadakis, Zaranis, \& Kalogiannakis, 2019). Given the widespread access to digital tools, most educational institutions in the developed world moved their courses, examinations, and other related activities online to contain the coronavirus (Wahab, 2020). Marinoni et al. (2020) reported that over 85 percent of educational institutions in developed countries and Asia migrated into the online environment after the closure of schools. A study across 20 countries by Crawford et al. (2020) focusing on education delivery during the COVID-19 pandemic revealed that most European institutions had deployed synchronous and asynchronous online learning approaches. Over 98 percent of schools in China have access to the internet, and during the COVID-19 lockdown, China 
successfully implemented online learning with over 90 percent participation by learners (Zhou, Li, Wu, \& Zhou, 2020). In some Middle East countries, educational institutions were required to provide statistics on how many students logged into various online platforms during the COVID-19 pandemic (Crawford et al., 2020). About 270 million students in China conducted their courses online, supported by about 20 million teachers during the outbreak of the COVID-19 (Zhou, Li, Wu, \& Zhou, 2020).

Several governments in developing countries have crafted policies that support mobile learning implementation to support 21st-century teaching and learning (Lam \& Duan, 2012). Bennett and Maton (2010) postulated that educational institutions should reform from their traditional teaching and learning methods and embrace new technologies popular with today's generation. Mangwaya et al. (2013) noted that many countries in the Global South relied on traditional face-to-face teaching. The sudden transition to the online environment was sudden, with most governments unprepared. Marinoni et al. (2020) reported that only 29 percent of educational institutions in Africa were able to move into the online environment during the COVID-19 lockdown. This means that most learners have not received any education after the school's closure, and received little or no communication from their teachers, causing anxiety. The past 20 years have seen China devoting resources to support the widespread online teaching deployment, and this initiative has been bearing fruits during the COVID-19 lockdown (Zhou, Li, Wu, \& Zhou, 2020). Zaranis et al. (2013) reported that the Indian government built a cheap tablet, sold to learners at USD35.00. The Turkish government spent USD8 billion to purchase 15 million tablets distributed to school-going children throughout the country to enhance teaching and learning (Zaranis et al., 2013). The government of Thailand issued 800000 laptops to most learners (Lam \& Duan, 2012). During the outbreak of the COVID-19, education institutions in Indonesia were closed, with teaching and learning conducted remotely using ICTs (Mailizar, Maulina, \& Bruce, 2020).

Today's learners do not need to adapt to digital media as their lives are driven by it since birth; therefore, online is not foreign (Prensky, 2010). The term "digital natives" was coined by Prensky in the year 2000 after realising that digital devices such as smartphones and the internet influenced and shaped young people's lives. Howe and Strauss (2003) branded this generation of learners as millennials, who display so much ease and talent around the internet and related technologies. Bennett and Maton (2010) described today's learners as the tech-savvy generation whose lives are engrossed in pervasive computing devices. Studies have revealed that 94 percent of teenagers go online every day to access educational, social networking, and shopping sites, check their phones 150 times a day and send at least 110 text messages (Brody, 2017; Pew Research Center, 2015). Young people spend many hours glued to digital technologies of different kinds (Gartrell, 2014), and the education system could take advantage of using digital media for remote-based learning.

Kalogiannakis and Papadakis (2019) posited that smartphones and tablets offer a more feasible way of learning outside the traditional classroom environment. In developing countries, the mobile phone is the most affordable computing device by which most learners can access learning (Boulos et al., 2011). Young people have taken advantage of portable devices as they support on the go learning and do not require learners to sit before a table to learn; this means that learning is ubiquitous and is not limited by space or time (Radich, 2013). Asterhan and Rosenberg (2015) contended that learners who used mobile instant messages to work collaboratively achieved better grades than those who did not. Other scholars noted that mobile applications ranked higher than all other technologies in terms of student motivation, interaction, and engagement and should be deployed to support teaching and learning (Neumann, 2016; Yokota \& Teale, 2014). Barry et al. (2014) concluded that learners who used mobile phones agreed that they could simply engage their peers, which optimised the learning process resulting in better grades.

Radio is a powerful mass medium that can broadcast educational content simply and more cheaply, reaching to the most remote and most deprived populations in developing countries (Nyarko \& MateKole, 2016). Radio broadcasts can improve access to learning content to rural learners and bridge the divide with their urban counterparts. Notwithstanding the promises of effective learning provided by radio broadcasts, the medium's efficacy has been questioned, especially as a teaching tool in the 21 st-century.

A study conducted in Namibia revealed that 67 percent of the population had radio access and that learners spent an average of six hours listening to radio programs such as news, entertainment and did not regard radio as a tool for learning (Beukes, 2006). Radio broadcasts were used for English language lessons in Kenya to help the community, which had embraced street slang, which affected school children, and the intervention proved successful (Odera, 2011). Kurrien (2008) noted that when correctly set up, radio lessons can be engaging as they could include drama and stories, which can resonate with the learners' realities resulting in active learning. Community radio stations in Ghana involved marginalised local communities in the production of content which served their needs, and this helped in promoting lifelong learning (Mckay, 2010). Adegbija et al. (2013) noted that campus radios established in Nigeria lacked trained broadcasters and instructional designers to create compelling content. Twenty-four tertiary institutions in Nigeria established campus radio stations to support broadcast teaching, and the majority-owned by institutions offering free distance learning (Adegbija et al., 2013). Potter and Naidoo (2006) reported that 48000 teachers and 1.6 million learners participated in radio learning programs in South Africa, whose annual cost was an astonishing US $\$ 3.00$ per learner.

\section{THEORETICAL BACKGROUND}

\section{Learning Styles}

Learning takes place through different perspectives, such as instructivism and constructivism. The instructivist theory upholds that knowledge flows unidirectionally from the instructor to the learners who must accept this knowledge without questioning or reasoning (Onyesolu et al., 2013). This paradigm considers the transmission and reception of knowledge as a critical component (Olusegun, 2015). Learners are passive recipients of knowledge who must memorise the information. Learning is pre-dominantly teacher-centred. In the constructivist paradigm, the learner is actively involved in constructing new knowledge and is, therefore, not a passive receiver (Taber, 2006). Learners create new knowledge as they discover further information by analysing old information against new and discarding aspects that have become redundant (Fosnot, 2005). Constructivists believe that learning is collaborative, learner-centred, where learners determine how they 
learn, by actively constructing knowledge, and that the teacher provides a facilitating role rather than being the sole constructor of knowledge (Olusegun, 2015). Other common learning styles include independent, collaborative, participant and dependent learning (Jose, Berry, \& Andrews, 2019). As the world confronts the realities of COVID-19, the Zimbabwean education system should provide learning experiences modelled around the constructivist's perspective. Learners should take charge of their learning in remote learning, as there is little to no monitoring from the teachers.

\section{Remote-Teaching through Radio}

Murillo (2010) contended that the installation of a small transistor radio costs of a few thousand dollars and required little maintenance and could serve the school or a cluster of the schools, including the community. Radio cannot support the learning styles that were noted by Jose et al. (2019) except to reinforce teachers-centred learning paradigm. While the use of radio in education is welcome, scholars question its extent and role in the learning process. For example, Holmberg (1985) only saw radio as playing a complementary role in supporting distance and regular face to face teaching methods. Radio has limitation such as passive and unidirectional access to content, which cannot be played back for content analysis and comprehension (Beukes, 2006). For radio to be interactive, Potter and Naidoo (2006) suggested that there was a need to use radio cassettes and Compact Discs (CDs). Student engagement could be aided through activities such as dividing lessons into segments for learners who can later replay and learn at their own time. Radio ownership and access in Zimbabwe are low, and for radio to succeed, it has to compete with other visual media, which appeal more to learners. McAlister (2009) posited that learners preferred a learning environment that offered multi-sensory engagement, such as multimedia. The use of two-way radio communication can improve learner engagement and offers interactive learning through engagement and immediate learner feedback (Kurubacak \& Yüzer, 2004).

Unlike textbooks that learners can read at any time, radio programs are time-bound with no repeats (Kurrien, 2008). In Zimbabwe, where there are no dedicated radio stations for educational programs, learners may miss out on re-listening for more comprehension, and repeating the programs may not be possible. Potter and Naidoo (2006) noted that radio programs do not necessarily improve the standard of teaching and learning but offered a low-cost means of delivering content to remote learners and reaching out to many learners. To deliver content to 15 grades/levels of learners in primary and secondary schools doing over ten subjects, Zimbabwe will rely on three radio stations that are already broadcasting general content to the nation. Despite the known limitations of instruction through radio, the Zimbabwean context presents its complexities. These include low penetration, a limited number of radio stations in the country, and lack of community radio stations to offer effective remote teaching and learning.

\section{Remote-Teaching through Television}

Television (TV) could also be used as a teaching and learning medium. In South Africa, the South African Broadcasting Corporation $(\mathrm{SABC})$, through $\mathrm{SABC}$, has managed to integrate remote learning into its programming. Teachers can effectively present audio-visual content to learners using television to help learners grasp concepts faster (Munene \& Mutsotso, 2019). One advantage of using tv for teaching and learning is that it supports audio-vision, enhancing the learning experience. Munene and Mutsotso (2019) underlined that television stimulates sensory senses through audio-visuals, improving teaching and learning. Television broadcasts have the potential to reach a larger audience and support remote learning during the COVID-19 pandemic. However, the chances of remote learning through television in Zimbabwe are limited as the country has one television channel, which cannot support teaching during the lockdown. Again, TV ownership is low, with 40 percent of the households having access to a television (Zimstats, 2018). One notable disadvantage of using TV is that it is not portable and offers little flexibility for today's learners who prefer to learn on the go. The TV is lacking in supporting the learning styles that were raised by Jose et al. (2019).

\section{Remote-Teaching through Digital Media}

Several studies have concluded that ICTs play a pivotal role in preparing learners for the 21 st-century skills, and in developing countries, mobile phones are the most accessible ICT gadgets (Kalogiannakis \& Papadakis, 2019; Maphosa, 2020). Digital media supports simple educational websites to learning environments supported by animation, virtual environments and tools that foster student engagement which stimulates cognitive processes and critical thinking. Zhou et al. (2020) contended that digital media breaks time limitations and provide high-quality, non-delayed live interactive classrooms in multi online classes. Digital technologies allow teachers to access massive resources that enrich the teaching material, ensuring that learners access rich, practical and real-time teaching. The conversion to online learning will enable learners to access content 24hours per day and improves communication with teachers. Mouchantaf (2020) reported that digital technologies improved student access to the teacher through various communication channels. Wahi et al. (2011) affirmed that digital technologies enable learners to generate content through collaborative work and has since transformed how teachers apply teaching materials in the classroom, thus transforming mainstream education. Digital technologies have enriched learning through animation and videos that support interactive learning environments (Wahab, 2020). One attraction brought by digital technologies is collaborative learning, where learners can subdivide a task, and each tackles their bit and each member accounts to the group. Today's young people prefer to learn on the go or just-in-time through unscheduled chunk-sized learning associated with mobile devices (Ngesi et al., 2018). The integration of technology in the class is not the ultimate motive; instead, teachers must help learners extend their learning possibilities by avoiding the passive use of non-interactive linear media (Gartrell, 2014).

The online world is proving to be more flexible, and engaging than the physical one in some instances, and learners have acknowledged that the online world is often more intimate than the physical one (Liang \& Chen, 2012). Learners can access content several times, review the learning resources, and teachers can monitor their progress. Karchmer-Klein and Harlow-Shinas (2012) reiterated that educators should transform their programs to match the new 21st-century skills as they prepare learners for future jobs. Learners in most developing countries do not have the financial resources to purchase textbooks and rely on mobile phones, which allow them to download course content (Ngesi et al., 2018). Therefore, educators must design a curriculum that is compatible with m-learning. Digital media can support all the learning styles that were raised by Jose et al. (2019) such as independent, collaborative, participant and dependent learning. During the COVID- 


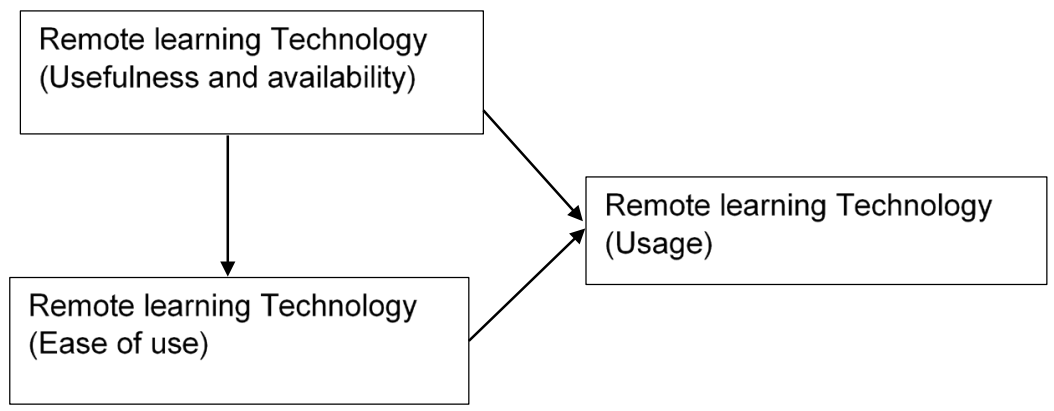

Figure 1. Modified TAM use (Davis, 1989)

19 lockdown, students can use digital media to access quality education through different constructivist based learning styles regardless of location, pace, and time constraints.

\section{PROBLEM STATEMENT}

When a crisis such as floods, earthquake or a natural disaster occurs, quite often everyday life is affected, and different institutions respond differently to such a calamity. This paper responds to the Zimbabwean government's adoption of radio broadcasts as the primary technology to support remote-based teaching for secondary schools during the COVID-19 lockdown (MoPSE, 2020). The paper sought to assess the suitability of radio as the primary means to support remotebased teaching. Prenksy (2010) asked whether old ways of learning should be forced on the digital natives or have the digital immigrants who are policymakers, and teachers learn to use the new methods of teaching. As the coronavirus spread across the world, governments enforced social distancing measures characterised by stay-at-home strategies and the closure of schools and other learning facilities. Contextually, Zimbabwe's radio penetration is low, with weak to no signal in some regions, especially those in the country's southern parts. While 30 percent of the population has radio access, mobile phone ownership per household is over 90 percent. These contextual dynamics led to the careful examination and evaluation of the suitability of available technologies in enriching student learning during the COVID-19 lockdown in response to the government's announcement on the use of radio broadcasts as the primary tool to support remote teaching.

\section{RESEARCH QUESTIONS}

i. What is the educational technology landscape in Zimbabwe? Moreover, is radio broadcast the most suitable technology for facilitating remote-based teaching for secondary schools?

ii. What are the main constraints in the uptake of remote-based teaching?

iii. Which technology is suitable for remote teaching, given the unique circumstances of learners in Zimbabwe?

\section{CONCEPTUAL FRAMEWORK}

The study utilised an adapted Technology Acceptance Model (TAM), developed by Davis (1989), as shown in Figure 1, to gather the opinions and practices of teachers regarding access to and use of educational technologies.TAM uses two primary constructs, perceived usefulness (PU) and perceived ease of use (PEOU), to determine technology adoption. PU is the belief that using new technology will increase an individual's performance. PEOU is a belief that new technology requires less effort to achieve the same goals. Several scholars have applied TAM for evaluating the application of different ICTs in education (Collis, Oscar, \& Pals, 2001; Kalogiannakis \& Papadakis, 2019; Mahdizadeh, Biemans, \& Mulder, 2008; Neofotistos \& Karavakou, 2018; Teo, 2013). Several studies conducted in Western countries applied the TAM, with fewer studies conducted in the African context (Teo, 2013). Therefore, this study adds more literature on its application. The model uses constructs to evaluate the appropriateness and usage of teaching technologies by secondary school teachers. The adapted model enables the researcher to contextualise the usage of different technologies for teaching. Today's education system is experiencing a mixed reality where the physical and online worlds are converging. This study considered constructs that measured the suitability, availability, cost, ease of use, and usefulness of available technologies to support teaching and learning during the COVID-19 lockdown.

\section{METHODOLOGY}

The study used a survey research design to explore the opinions, practices, and factors that influence educational technology adoption by secondary school teachers. A survey research design was used, which utilised quantitative research approaches. Due to COVID-19 social distancing requirements, an online questionnaire was considered a feasible way of soliciting teachers' information in response to the inquiry's research questions. The study also pays particular attention to radio use by school teachers in line with the implementation of radio broadcasts by the government of Zimbabwe. TAM was used to develop a questionnaire that evaluated how the available technologies supported 21 st-century teaching and learning during school closure. The research focused on teachers in Zimbabwe's southern region, composed of three provinces, namely Bulawayo, Matabeleland North, and Matabeleland South.

\section{Instrument}

The adapted TAM by Davis (1989) and reviewed literature guided the construction of the questionnaire. The study used a 20-question survey instrument to solicit for information. The first part of the questionnaire utilised defined responses related to the demographic data related to age, gender, level of education etc. Further questions raised relate to device ownership, remote teaching status, and barriers 


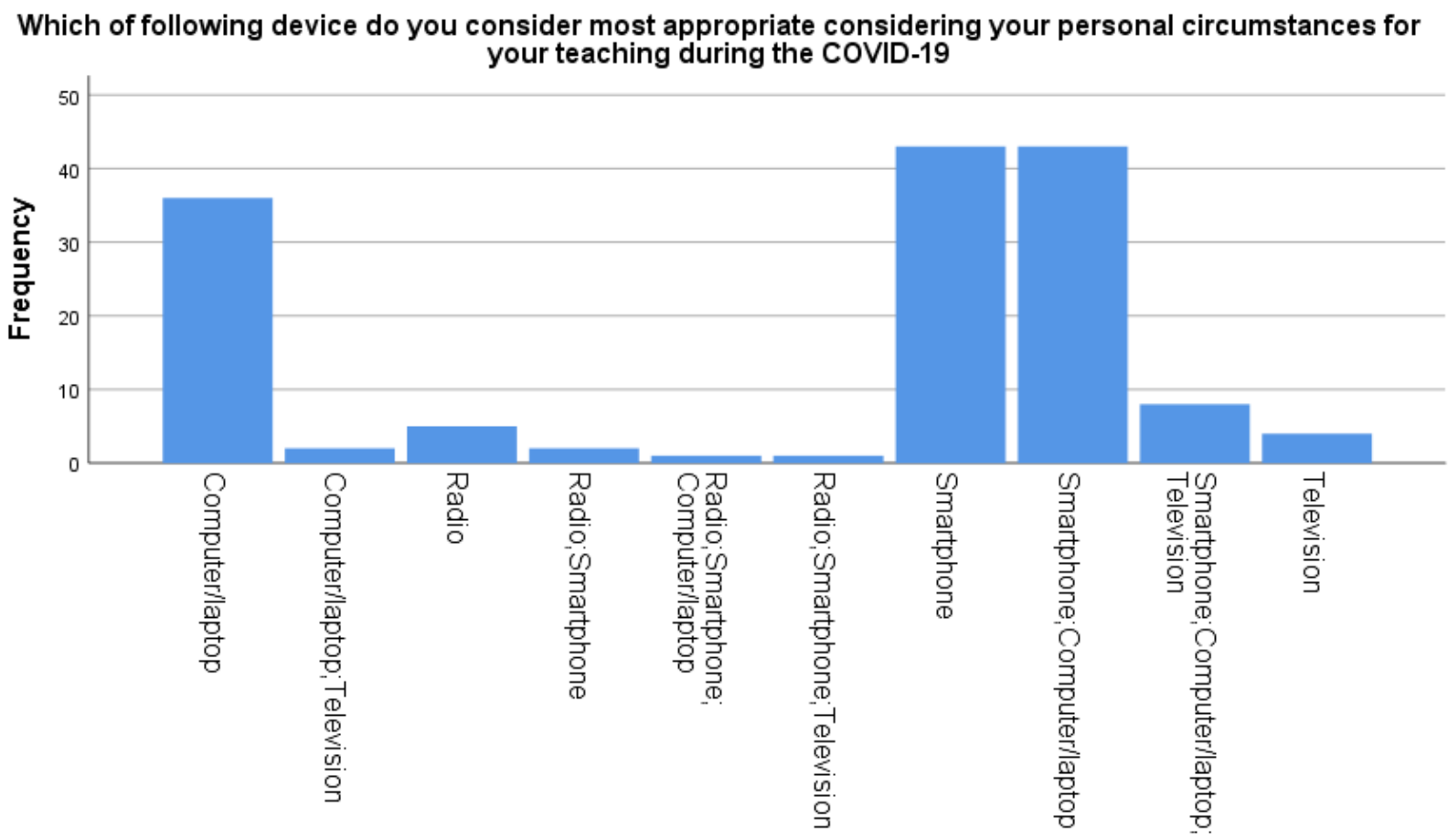

Figure 2. Device most considered appropriate for remote learning

Table 1. State of remote-based learning

\begin{tabular}{cccc}
\hline Remote-based learning & Frequency & Percent & Cumulative percent \\
\hline No, I do not use remote-based learning & 39 & 26.9 & 26.9 \\
\hline Through broadcast radio & 7 & 4.8 & 31.7 \\
\hline Through online teaching & 99 & 68.3 & 100.0 \\
\hline Total & 145 & 100.0 & \\
\hline
\end{tabular}

to uptake from the participants. The remaining part of the questionnaire evaluated the perceived usefulness and ease of use available ICTs for remote based learning. The questions used a 5-point Likert scale whose responses were 5 for strongly agree, 3 for neutral, and 1 for strongly disagree. The questionnaire was distributed after the schools' closure during remote-based teaching. The link to the questionnaire was emailed to participants and sent to their WhatsApp groups. The questionnaire was piloted to lecturers in the Department of Educational Foundations at Lupane State University to determine the instrument's understandability and usability. The feedback was incorporated to improve the questionnaire. The instrument's Cronbach's alpha reliability score is 0.86 , and this means that the questionnaire's reliability was acceptable as it was above average.

\section{RESULTS}

The study targeted 300 teachers from Zimbabwe's southern region, and 145 usable responses were received, giving a response rate of 48.3 percent. The respondents were composed of 85 (58.6 percent) females and 60 (41.4 percent) males. About 92.2 percent of teachers had access to a smartphone, 55 percent had access to a computer/laptop, 34.6 percent of the teachers had access to a radio, and 40.7 percent had access to a television. Statistics on access to radio are consistent with survey results by Zimstats (2018), which established that 29.1 percent of the Zimbabwean population has access to the radio, and 40 percent has access to television. Computer access was lower than a South African study by Hart and Laher (2015), who found that 100 percent of the educators had access to a computer at home. Teachers selected a device they considered most appropriate for remote teaching. Figure 2 shows that 29.7 percent chose a smartphone, and another 29.7 percent selected a combination of the smartphone/laptop/computer, 2.8 percent chose television, while 3.4 percent considered radio. The teachers also selected a combination of radio/smartphone with 1.4 percent, radio/smartphone/computer/laptop was 0.7 percent and radio/smartphone/television was 0.7 percent. The findings are congruent with Neofotistos and Karavakou (2018) 's conclusions, who noted that lack of access to educational technology in Greece was hindering the full utilisation of educational software. The high usage of smartphones in the study is a result of the COVID-19 lockdown where teachers could not access their school computers, and this is contrary to results of studies in Tanzania, which highlighted that teachers were not using the smartphone as a tool for academic purposes (Gibbons et al., 2018; Mfaume, 2019). In contrast to these findings, Twum (2014) observed that most teachers in Ghana did not recognise the smartphone's potential in supporting teaching and learning.

With regards to remote learning, Table 1 shows that 68.3 percent of the participants engaged in online education, 4.8 percent used radio broadcasts, while 26.9 percent were not conducting any remote-based teaching. Close to a third of the teachers were not involved in remotebased learning.

WhatsApp and Facebook were the most used teaching tools by 51 percent of the participants. About 6.9 percent used a Learning 
Table 2. Tools used for remote-based learning

\begin{tabular}{|c|c|c|c|}
\hline Remote-based learning tool used & Frequency & Percent & Cumulative percent \\
\hline A combination of Social media and LMS & 19 & 13.1 & 13.1 \\
\hline LMS (Moodle, Google Classroom) & 10 & 6.9 & 20.0 \\
\hline None of the above, not using any & 39 & 26.9 & 46.9 \\
\hline Social Media (e.g. WhatsApp, Facebook) & 74 & 51.0 & 97.9 \\
\hline Television and radio broadcast & 3 & 2.1 & 100.0 \\
\hline Total & 145 & 100.0 & 100.00 \\
\hline
\end{tabular}

Table 3. Pearson's correlation between the variables

\begin{tabular}{ccccc}
\hline & $\begin{array}{c}\text { Lack of access to } \\
\text { equipment }\end{array}$ & $\begin{array}{c}\text { Institutional } \\
\text { culture }\end{array}$ & Cost of data & $\begin{array}{c}\text { Lack of training } \\
\text { Suitability of } \\
\text { equip }\end{array}$ \\
\hline Lack of access to equipment & - & $\begin{array}{c}\text { Availability of } \\
\text { equip }\end{array}$ & & \\
\hline Institutional culture & $.532^{* *}$ & - & - & - \\
\hline Cost of data for teaching & .126 & -.036 & .116 & .190 \\
\hline Lack of training & $.354^{* *}$ & .288 & $.445^{* *}$ & .181 \\
\hline Suitability of equip & .168 & .125 & .112 & .211 \\
\hline Availability of equip & .172 & .256 & & - \\
\hline
\end{tabular}

Note. ${ }^{*} \mathrm{p}<.05$ (2-tailed). ${ }^{* *} \mathrm{p}<.01$ ( 2 -tailed $)$

Management System (LMS) such as Moodle and Google classroom, and 13.1 percent used a combination of social media and LMS and learning, as shown in Table 2. In a related study, Maphosa et al. (2020) established that 77 percent of learners used WhatsApp for learning during the COVID-19 lockdown. The low usage of an LMS is consistent with reports by the World Economic Forum that less than 25 percent of countries in the global south had set up platforms to support remote-based teaching and learning (Sharma, 2020). Radio and television broadcast was used by 2.1 percent, while 26.9 percent did not use any remote-based teaching tool. The findings are consistent with Bouhnik and Deshen (2014)'s work, who concluded that WhatsApp had found itself in the classroom even though teachers had not received training on its usage.

The majority of the respondents (92 percent) revealed that one crucial barrier to online learning was the cost of data; this is consistent with teachers' views in Tanzania who lamented that internet costs were a significant barrier to online content delivery (Mfaume, 2019). These challenges are similar to those found in a similar study in Malaysia, which included a slow network, device constraints, and untrained staff (May et al., 2012). The barriers raised in this study are comparable to those identified by Elemam (2016), where Sudanese teachers pointed out limited access to technology, resources, and training.

The majority of the respondents ( 65 percent) revealed that online teaching was easy to use. The findings are consistent with Awad and Salameh (2019); their findings revealed that 70 percent of faculty considered online learning to be easy to use. The survey results show that 68.7 percent of the teachers agreed that online learning promotes collaborative learning and interaction, while 12.5 percent disagreed, and 19.8 percent strongly disagreed. This is consistent with Tanzanian teachers' views, who agreed that the smartphone promoted collaborative learning and interaction amongst themselves and the learners through popular applications such as WhatsApp and Shule (Mfaume, 2019). About 76.2 percent of the respondents agreed that lack of institutional culture or plans to embrace digital technologies affected their use of online teaching; additionally, 77.6 percent also cited the lack of national policies. These findings are similar to Mupinga (2018) 's observations, who asserted that older administrators were oblivious of the potential of technology in the classroom. Leontyeva (2018) concluded that the lack of national or institutional policy affected the availing of resources to support technology-based learning. The findings are consistent with work by Tariq et al. (2018), in Malaysia who opined that institutional culture was a strong predictor of online usage.

The correlations between the factors that affect technology use and adoption were evaluated using Pearson's correlation coefficient, as shown in Table 3. A strong positive correlation was observed between lack of institutional culture and lack of access to equipment ( $r=.532$, $\mathrm{p}<.01$ ), this implies that the absence of an institutional vision to adopt educational technology, negatively affects the provision of appropriate educational technology to the teachers. Additionally, a strong positive correlation was observed between the cost of data for teaching and the suitability of the equipment $(\mathrm{r}=.445, \mathrm{p}<.01)$. This means that data costs have a significant influence on the suitability of equipment. The analysis shows a negative correlation between the cost of data and institutional culture $(\mathrm{r}=-0.036, \mathrm{p}<.01)$. The price of data and availability of equipment, access to equipment, and the cost of data, lack of access to equipment and suitability of equipment were not statistically significant.

\section{DISCUSSION}

This study contributes to the literature on the use of educational technologies to support remote-based teaching during the COVID-19 pandemic. The extended school closure will force many learners to drop out of school due to lack of access to educational resources. Reviewed literature shows that today's learners should access resources that enable them to build skills and competencies for participating in the knowledge economy as confident digital citizens. In answering the first research question, the results show that the adoption of radio broadcast by the Zimbabwean government for teaching and learning may not be the best tool based on the teacher's views. The radio broadcasts support instructivist learning style, which is not suitable for 21-st century learning. In responding to the second research question, the challenges faced by Zimbabwean secondary school teachers in conducting remotebased education during the COVID-19 pandemic were the prohibitive cost of data, lack of appropriate devices, digital skills, and wrong choice 
of technology to support teaching by the government. The findings are consistent with work by Liang and Chen (2012); Neofotistos and Karavakou (2018), who noted that the provision of requisite equipment and software for teaching was critical. They concluded that some significant barriers to online learning were related to the teacher's access to equipment, lack of institutional policies and rationale, financial constraints that hinder access to data, and lack of digital skills to create appropriate content. These constraints negatively affected the perceived ease of use of educational technology. Tariq et al. (2018) also concluded that challenges such as lack of technological skills by teachers and learners and culture negatively affected online learning implementation. In response to the third research question, the study revealed that teachers found mobile phones and social media as the most feasible tools for remote based teaching. The results show that online-based technologies are the most preferred and viable means of education due to high mobile phone penetration rates. The teachers perceived that digital technologies were easy to use and useful compared to proposed radio broadcasts. Digital technologies support constructive learning. Educators and policymakers must maximise the benefits offered by digital media to enhance young people's learning experiences during pandemics such as the COVID-19, which has forced the abandonment of face to face learning. Therefore, the broad-based measures taken to protect the learners by closing schools will widen the learning disparities between schools that have access to technology and those that do not have, such as rural schools. This was highlighted by 26.9 percent of the teachers were not involved in remote based teaching.

\section{CONCLUSION AND RECOMMENDATIONS}

The outbreak of the COVID-19 virus has presented new opportunities to consider alternative and flexible delivery of educational content to face-to-face. If properly managed, the pandemic can also catalyse developing countries to leapfrog developed nations by crafting policies and strategies to strengthen their education system's resilience. Developing countries can explore innovative ways of sustaining online pedagogies and teacher's training as this may become the new norm for the next coming years. The study focused on teachers from three provinces of Zimbabwe, a least developed country; these findings can help policymakers decrease the educational and digital divide. The study's findings reveal that the availability and suitability of technology are paramount in ensuring the success of remote-based teaching as teachers preferred the smartphone and the computer/laptop instead of radio broadcasts. Most of the teachers chose social media tools and LMSs. The selected teaching tools can support all the learning styles that were raised by Jose et al. (2019) such as independent, collaborative, participant and dependent learning. Barriers identified from the study that affected the adoption of technology-based teaching and learning were lack of infrastructure, cost of data, teacher's skills, learner's access to the internet and computing devices, management support, and the institution's culture. The COVID-19 lockdown requirements negatively affected the size of the sample used, which may affect the generalisability of the results. Future studies could use a larger sample to be more representative.

The study recommends that the government and other partners invest in ICT infrastructure to support remote-based teaching and learning. Educator's training in the use of digital media will also assist in ensuring that learning continues amid natural disasters that interrupt face-to-face learning. Partnerships with internet service providers and other stakeholders to offer cheaper or free access to educational content during the COVID-19 lockdown will be vital. The government must demonstrate its commitment to embracing 21st-century learning by the crafting national policies that support modern teaching and learning. Stakeholders should find ways to address the current learning crisis and future ones by implementing strategies that seemed challenging to implement. This research provides a baseline for other researchers to explore how educational technology could support remote-based teaching in a developing country. The study may help policymakers and educators enact policies and strategies that can address current and future disruptions.

\section{REFERENCES}

Adegbija, M., Fakomogbon, M., \& Adebayo, M. (2013). Roles of broadcast media for instructional delivery in open and distance learning: Nigeria as a state a case study. European Scientific Journal, 9(23), 1857-7881.

Alenezi, A. (2019). Effectiveness of Educational Technology Applications in Saudi Arabian Secondary Schools. Journal of Informatics and Mathematical Sciences, 11(2), 221-233.

Awad, M., \& Salameh, K. (2019). Evaluating Learning Management System Usage at a Small University. ICISDM, 2019 (pp. 89-102). ACM. https://doi.org/10.1145/3325917.3325929

Baldwin, S., \& Trespalacios, J. H. (2017). Evaluation instruments and good practices in online education. Online Learning, 21(2). https://doi.org/10.24059/olj.v21i2.913

Bedesem, P. L., \& Arner, T. (2019). Mobile Learning in and out of the K-12 Classroom. In D. B. Khosrow-Pour (Ed.), Advanced Methodologies and Technologies in Modern Education Delivery (pp. 839-849). Hershey IGI Global. https://doi.org/10.4018/978-15225-7365-4.ch065

Beukes, J. R. (2006). Using Radio in Innovative ways to support ODL Learners in Namibia: Opportunities, Challenges, and Achievements. Paper presented at The Fourth Pan-Commonwealth Forum on Open Learning (PCF4). Retrieved on 21 April 2020 from http://pcf4.dec.uwi.edu/viewpaper.php?id=178

Bouhnik, D., \& Deshen, M. (2014). WhatsApp goes to school: Mobile instant messaging between teachers and students. Journal of Information Technology Education: Research, 13, 217-231. https://doi.org/10.28945/2051

Collis, B., Oscar, P., \& Pals, N. (2001). A model for predicting the educational use of information and communication technologies. Instructional Science, 29(2), 95-125. https://doi.org/10.1023/ A:1003937401428

Crawford, J., Butler-Henderson, K., Rudolph, J., Malkawi, B., Glowatz, M., Burton, R., . . Lam, S. (2020). COVID-19: 20 countries' higher education intra-period digital pedagogy responses. Journal of Applied Teaching and Learning (JALT), 3(1), 9-28. https://doi.org/10.37074/jalt.2020.3.1.7

Davis, F. (1989). Perceived Usefulness, Perceived Ease of Use, and User Acceptance of Information Technology. MIS Quarterly, 13, 319-340. https://doi.org/10.2307/249008 
Elemam, A. E. (2016). Barriers to Implementation of Information and Communication (ICT) in Public Sudanese Secondary Schools: Teacher's Perspective. Journal of Sociological Research, 7(1), 33-43. https://doi.org/10.5296/jsr.v7i1.8956

Fosnot, C. (2005). Constructivism: Theory, perspectives, and practice (2nd ed.). New York: Teachers: College Press.

Gartrell, D. (2014). A Guidance Approach for the Encouraging Classroom. Cengage learning.

Gibbons, A., Galloway, D., Mollel, A., Mgoma, S., Pima, M., \& Deogratias, E. (2018). Mobile phone use in two secondary schools in Tanzania. Educational Information Technology, 23, 73-92. https://doi.org/10.1007/s10639-017-9586-1

Hart, S., \& Laher, S. (2015). Perceived Usefulness and Culture as Predictors of Teachers' Attitudes towards Educational Technology in South Africa. South African Journal of Education, 35(4), 1-13. https://doi.org/10.15700/sajev35n4a1180

ITU report. (2018, March 23). Measuring the Information Society Report. Retrieved on 10 May 2020 from ICT facts and figures: https://www.itu.int/en/ITU-D/Statistics/Documents/ publications/misr2018/MISR-2018-Vol-1-E.pdf

Jose, B., Berry, M., \& Andrews, L. (2019). Course Format and Student Learning Styles: A Comparison of Political Science Courses. American Journal of Distance Education, 33(4), 262-275. https://doi.org/10.1080/08923647.2019.1643697

Kabali, H. K., Irigoyen, M. M., Nunez-Davis, R., Budacki, J. G., Mohanty, S. H., Leister, K. P., \& Bonner, R. (2015). Exposure and use of mobile media devices by young children. Pediatrics, 136, 10441050. https://doi.org/10.1542/peds.2015-2151

Kalogiannakis, M., \& Papadakis, S. (2019). Evaluating pre-service kindergarten teachers' intention to adopt and use tablets into teaching practice for natural sciences. Int. J. Mobile Learning and Organisation, 13(1), 113-127. http://doi.org/10.1504/IJMLO.2019. 10016617

Karombo, T. (2018). Smartphone Users Over 50\% In Zim. Technomag. Retrieved on 5 October 2020 from https://itweb.africa/content/ VgZeyqJoEaLvdjX9

Kurrien, Z. (2008). The Use of Educational Radio for Improving the Quality of Teaching and Learning in Government Regional Medium Elementary Schools. New Delhi.

Kurubacak, G., \& Yüzer, V. (2004). Producing Interactive Educational Radio Programs for Distance Education. In B. Kitabı (Ed.), World Conference on E-Learning in Corporate, Government, Healthcare, and Higher Education 2004 (pp. 1587-1601). Washington DC: G. Richards.

Lam, J., \& Duan, G. (2012). A review of the mobile learning environment in the higher education sector of Hong Kong: Technological and social perspectives. In S. K. Cheung, J. Fong, L. Kwok, K. Li, \& R. Kwan (Ed.), Hong Kong (pp. 165-173). Springer. https://doi.org/10.1007/978-3-642-32018-7_16

Leontyeva, I. (2018). Modern distance learning technologies in higher education: Introduction problems. Eurasia Journal of Mathematics, Science and Technology Education, 14(10), em1578. https://doi.org/10.29333/ejmste/92284
Liang, R., \& Chen, D. V. (2012). Online Learning: Trends, Potential, and Challenges. Creative Education, 3(8), 1332-1335. https://doi.org/10.4236/ce.2012.38195

Mahdizadeh, H., Biemans, H., \& Mulder, M. (2008). Determining factors of the use of e-learning environments by university teachers. Computers \& Education, 51, 142-154. https://doi.org/10.1016/j.compedu.2007.04.004

Mailizar, A. A., Maulina, S., \& Bruce, S. (2020). Secondary School Mathematics Teachers' Views on E-learning Implementation Barriers during the COVID-19 Pandemic: The Case of Indonesia. EURASIA Journal of Mathematics, Science and Technology Education, 16(7), em1860. https://doi.org/10.29333/ejmste/8240

Maphosa, V. (2020). Using MyLSU app to enhance student engagement and promote a smart town at a rural university in Zimbabwe. Cogent Education, 7(1), 1823143. https://doi.org/10.1080/2331186X.2020. 1823143

Maphosa, V., Dube, B., \& Jita, T. (2020). A UTAUT Evaluation of WhatsApp as a Tool for Lecture Delivery During the COVID-19 Lockdown at a Zimbabwean University. International Journal of Higher Education (IJHE), 9(5), 84-93. https://doi.org/10.5430/ ijhev9n5p84

Marinoni, G., van't Land, H., \& Jensen, T. (2020). The impact of COVID19 on Higher Education around the world. Paris: International Association of Universities (IAU).

May, M., Fessakis, G., Dimitracopoulou, A., \& George, S. (2012). A Study on User's Perception in E-learning Security and Privacy Issues. IEEE 12th International Conference on Advanced Learning Technologies (pp. 88-89). IEEE. https://doi.org/10.1109/ICALT. 2012.145

McAlister, A. (2009). Teaching the millennial generation. American Music Teacher, 59(1), 13-15. https://doi.org/10.1177/000313130905 900113

Mfaume, H. (2019). Awareness and use of a mobile phone as a potential pedagogical tool among secondary school teachers in Tanzania. International Journal of Education and Development using Information and Communication Technology, 15(2), 154-170.

Mikre, F. (2011). The Roles of Information Communication Technologies in Education Review Article with Emphasis on the Computer and internet. Ethiopian Journal of Education and Science, 6(2), 1-16.

Montrieux, H., Vanderlinde, R., Schellens, T., \& De Marez, L. (2015). Teaching and Learning with Mobile Technology: A Qualitative Explorative Study about the Introduction of Tablet Devices in Secondary Education. PLoS ONE, 10(12), 1-17. https://doi.org/10.1371/journal.pone.0144008

MoPSE. (2020). Secondary Schools. Retrieved on 20 June 2020 from Ministry of Primary and Secondary Education: http://mopse.co.zw/secondary-school

Mouchantaf, M. (2020). The COVID-19 Pandemic: Challenges Faced and Lessons Learned Regarding Distance Learning in Lebanese Higher Education Institutions. Theory and Practice in Language Studies, 10(10), 1259-1266. https://doi.org/10.17507/tpls.1010.11

Munene, S., \& Mutsotso, N. (2019). Kibabii University use of television in promoting teaching and learning in schools. British International Journal of Education and Social Sciences, 6(5), 10-15. 
Mupinga, D. (2018). School-wide and Classroom Policies on the Use of Mobile Technologies: An Exploratory Study. The Journal of Technology Studies, 43(2), 70-79. https://doi.org/10.21061/ jots.v43i2.a.2

Neofotistos, V., \& Karavakou, V. (2018). Factors Influencing the Use of ICT in Greek Primary Education. Open Journal for Educational Research, 2(2), 73-88. https://doi.org/10.32591/coas.ojer.0202. 02073n

Ngesi, N., Landa, N., Madikiza, N., Cekiso, P., Tshotsho, B., \& Walters, M. L. (2018). Use of mobile phones as supplementary teaching and learning tools to learners in South Africa. Reading \& Writing Journal of the Reading Association of South Africa, 9(1), 1-12. https://doi.org/10.4102/rw.v9i1.190

Nyarko, N. Y., \& Mate-Kole, C. C. (2016). Proposing a contextual approach to pre-school teacher education in Ghana. Cogent Education, 3(1), 1-10. https://doi.org/10.1080/2331186X.2016. 1164020

OCHA. (2020, September 4). Zimbabwe situation. UNOCHA. Retrieved from https://reports.unocha.org/en/country/zimbabwe/

Odera, Y. F. (2011). Learning the English Language by Radio in Primary Schools in Kenya. US-China Education Review, 960-966.

Olusegun, S. (2015). Constructivism Learning Theory: A Paradigm for Teaching and Learning. Journal of Research $\&$ Method in Education, 5(1), 66-70.

Onyesolu, O., Nwasor, C., Ositanwosu, E., \& Iwegbuna, N. (2013). Pedagogy: Instructivism to Socio-Constructivism through Virtual Reality. International Journal of Advanced Computer Science and Applications, 4(9), 40-47. https://doi.org/10.14569/IJACSA.2013. 040907

Papadakis, S. (2018). Evaluating pre-service teachers' acceptance of mobile devices with regards to their age and gender: a case study in Greece. International Journal of Mobile Learning and Organisation, 4(2), 336-352. https://doi.org/10.1504/IJMLO.2018.10013372

Papadakis, S., \& Kalogiannakis, M. (2017). Mobile educational applications for children. What educators and parents need to know. International Journal of Mobile Learning and Organisation, 11(3), 256-277. https://doi.org/10.1504/IJMLO.2017.085338

Papadakis, S., Zaranis, N., \& Kalogiannakis, M. (2019). Parental involvement and attitudes towards young Greek children's mobile usage. International Journal of Child-Computer Interaction, 22, 1-12. https://doi.org/10.1016/j.ijcci.2019.100144

Pew Research Center. (2015, March 19). Internet Seen as Positive Influence on Education but Negative on Morality in Emerging and Developing Nations. Retrieved from https://www.pewresearch.org/global/ 2015/03/19/internet-seen-as-positive-influence-on-educationbut-negative-influence-on-morality-in-emerging-anddeveloping-nations/

Porter, G., Hampshire, K., Milner, J., Munthali, A., Robson, E., De Lannoy, A., \& Abane, A. (2015). Mobile Phones and Education in sub-Saharan Africa: From Youth Practice to Public Policy. Journal of International Development, 28, 22-39. https://doi.org/10.1002/jid.3116
POTRAZ. (2019). Abridged postal and telecommunications sector performance report. Harare. Retrieved from https://t3n9sm.c2.acecdn.net/wp-content/uploads/2020/03/ Abridged-Sector-Performance-report-4th-Q-2019pdf.pdf

Prensky, M. (2010). Teaching digital natives: Partnering for real learning (Vol. 9). Thousand Oaks: Corwin.

Pullen, D. (2015). The influence of the home learning environment on middle school students' use of ICT at school. Australian Educational Computing, 30(1), 1-25.

Radich, J. (2013). Technology and interactive media as tools in early childhood programs serving children from birth through age 8 . Every Child, 19(4), 18-27.

Sharma, N. (2020). Torn safety nets: How COVID-19 has exposed huge inequalities in global education. World Economic Forum. Retrieved from https://www.weforum.org/agenda/2020/06/torn-safetynets-shocks-to-schooling-in-developing-countries-duringcoronavirus-crisis/

Taber, K. (2006). Beyond Constructivism: The progressive research programme into learning science. Studies in Science and Education, 42, 125-184. https://doi.org/10.1080/03057260608560222

Talebiana, S., Mohammadia, H. M., \& Rezvanfar, A. (2014). Information and communication technology (ICT) in higher education: advantages, disadvantages, conveniences, and limitations of applying e-learning to agricultural students in Iran. Procedia - Social and Behavioral Sciences, 152, 300-305. https://doi.org/10.1016/j.sbspro.2014.09.199

Tariq, S., Ishak, B., \& Nafi, M. (2018). Measuring e-learning success with the extension of the technology factor in Delone \& Mclean IS success model. International Journal of Advanced Research, 6(11), 422428. https://doi.org/10.21474/IJAR01/8014

Teo, T. (2013). Efficiency of the technology acceptance model to explain pre-service teachers' intention to use technology. CampusWide Information System, 28(2), 93-101. https://doi.org/10.1108/10650741111117798

Wahab, A. (2020). Online and Remote Remote Learning in Higher Education Institutes: A Necessity in light of COVID-19 pandemic. Higher Education Studies, 10(3), 16-25. https://doi.org/10.5539/hes. v10n3p16

Wargo, E., Chellman, C., Budge, K., \& Davis, C. (2020). On the digital frontier: Stakeholders in rural areas take on educational technology and schooling. Journal of Research on Technology in Education, 1-19. https://doi.org/10.1080/15391523.2020.1760753

Zaranis, N., Kalogiannakis, M., \& Papadakis, S. (2013). Using Mobile Devices for Teaching Realistic Mathematics in Kindergarten Education. Creative Education, 4(7A1), 1-10. https://doi.org/10.4236/ce.2013.47A1001

Zhou, L., Li, F., Wu, S., \& Zhou, M. (2020). “School's Out, But Class's On”, The Largest Online Education in the World Today: Taking China's Practical Exploration During The COVID-19 Epidemic Prevention and Control as An Example. Best Evid Chin Edu, 4(2), 501-519. https://doi.org/10.15354/bece.20.ar023

Zhu, X., \& Li, J. (2020). Education in and After COVID-19: Immediate Responses and Long-Term Visions. Postdigital Science and Education, 2, 695-699. https://doi.org/10.1007/s42438-020-00126-3 
Zimstats. (2018, December). Poverty, Income, Consumption, and Expenditure Survey 2017 Report. Retrieved from http://www.zimstat. co.zw/sites/default/files/img/zwe-2017-pices-report.pdf 